\title{
ASESMEN PEMECAHAN MASALAH OPEN-ENDED UNTUK MENGUKUR PROFIL BERPIKIR KREATIF MATEMATIS SISWA BERDASAR GENDER
}

\author{
Cholis Sa'dijah' \\ Hajjah Rafiah ${ }^{2}$ \\ Muhana Gipayana ${ }^{3}$ \\ Abdul Qohar ${ }^{4}$ \\ Lathiful Anwar ${ }^{5}$ \\ Universitas Negeri Malang ${ }^{1,3,4,5}$; STKIP PGRI Banjarmasin ${ }^{2}$ \\ Jl. Semarang No. 5 Malang \\ e-mail: cholis.sadijah.fmipa@um.ac.id
}

\begin{abstract}
The purpose of this qualitative research is describing open-ended problem solving assessments for measuring the profile of student's mathematical creative thinking, and describing student's mathematical gender-based creative thinking profile. The assessments forms were open-ended problem solving sheet and interview guide. The research subjects were 3 female and 3 male sixth graders at one of elementary school in Malang, whose mathematical creative thinking capability regarded as high, fair, low level for each gender group. The students whose mathematical creative thinking high have all the three aspects of creative thinking: fluency, flexibility, and originality aspects of creativity. The students who have fair level of mathematical creative thinking fulfill only two aspects that are fluency and flexibility aspects. The students whose mathematical creative thinking low have only fluency aspect. Female students solve mathematical problems more fluently than boys. The male student who has high level of mathematical creative thinking has visual spatial ability better than the same level female student. Also the high mathematical profeciency female student has better mathematical reasoning ability than the male student of the same level.
\end{abstract}

Key words: assessment, open-ended problem solving, mathematical creative thinking, gender.

\begin{abstract}
Abstrak: Tujuan penelitian ini mengkaji asesmen pemecahan masalah open-ended untuk mengukur profil berpikir kreatif matematis siswa dan mengkaji profil berpikir kreatif matematis siswa berdasar gender. Asesmen pemecahan masalah open-ended berupa lembar-lembar pemecahan masalah open-ended dan pedoman wawancara untuk mengukur profil berpikir kreatif matematis siswa. Penelitian ini merupakan penelitian kualitatif. Subjek penelitian terdiri dari tiga laki-laki dan tiga perempuan siswa kelas VI di satu sekolah dasar di kota Malang yang masing-masing berkategori berpikir kreatif matematis tinggi, sedang, dan rendah. Siswa lakilaki dan siswa perempuan yang berkategori berpikir kreatif matematis tinggi memenuhi aspek kelancaran, keluwesan, dan keaslian, yang berkategori sedang memenuhi aspek kelancaran dan keluwesan, sedangkan yang berkategori rendah hanya memenuhi aspek kelancaran. Perbedaan yang terjadi muncul pada aspek kelancaran, yaitu siswa perempuan lebih lancar daripada siswa laki-laki. Siswa laki-laki yang berkategori berpikir kreatif matematis tinggi memiliki kemampuan visual spasial yang tinggi, sementara siswa perempuan yang berkategori berpikir matematis tinggi memiliki penalaran matematis yang tinggi.
\end{abstract}

Kata kunci: asesmen, pemecahan masalah open-ended, berfikir kreatif matematis, gender. 
Matematika dapat digunakan untuk mengembangkan kreativitas (Sriraman, 2009; Brunkalla, 2009; Nadjafikhah, et al, 2011; Voica, 2012; Sa'dijah, 2013; Svecová, et al, 2014; Sharma, 2014). Hal ini karena hakikat matematika berkenaan dengan ideide, struktur-struktur, dan hubungan-hubungan yang diatur menurut logika. Suatu kebenaran matematika dikembangkan berdasarkan pada alasan logis, dan kerja matematika antara lain membuat dan menguji hipotesis, mencari analogi, melakukan koneksi dan komunikasi, membuat representasi, membuat generalisasi, membuktikan teorema, dan memecahkan masalah. Sementara untuk melakukan kegiatan-kegiatan ini diperlukan beberapa keterampilan berpikir tingkat tinggi yaitu salah satunya adalah berpikir kreatif.

Kreativitas dalam matematika lebih menekankan pada proses yaitu proses berpikir kreatif. Siswono \& Rosyidi (2005) menyebut kreativitas sebagai produk dari berpikir kreatif. Oleh karena itu, kreativitas matematika sering disebut dengan isilah berpikir kreatif matematis. Menurut Mahmudi (2010), "istilah kreativitas matematika atau berpikir kreatif matematis dipandang memiliki pengertian yang sama sehingga dapat digunakan secara bergantian." Dalam penelitian ini, istilah kreativitas matematika dan berpikir kreatif matematis juga digunakan secara bergantian karena diasumsikan memiliki definisi dan arti yang sama.

Berpikir kreatif matematis erat kaitannya dengan pemecahan masalah (NCTM, 2000; Chamberlin \& Moon, 2005; Mann, 2009; Baran, et al, 2011; Sriraman, Haavold, \& Lee, 2013). Kreativitas matematika ditunjukkan dengan kemampuan dalam memecahkan masalah, khususnya masalah atau situasi matematika (Baran, et al, 2011). Didukung oleh Chamberlin \& Moon (2005) yang menyatakan bahwa kreativitas adalah proses berpikir matema-tikawan terkait pemecahan masalah non rutin. Oleh karena itu, beberapa ahli meyakini bahwa pemecahan masalah sebagai salah satu dari aspek berpikir kreatif matematis (Mann, 2009; Sriraman, et al, 2013). Selain itu, Principles and Standard for School Mathematics (NCTM, 2000) juga mengusulkan bahwa siswa perlu diberikan masalah yang menantang yang dapat merangsang perkembangan berpikir kreatif matematika mereka. Karena kegiatan pemecahan masalah memungkinkan siswa untuk mengasah keterampilan berpikir kreatif mereka dalam menemukan berbagai penyelesaian yang tepat.

Berdasarkan hasil wawancara pada studi pendahuluan dengan salah satu guru kelas VI SDI Surya Buana Malang pada tanggal 15 Desember 2015 diperoleh fakta bahwa siswa-siswi kelas VI SDI Surya Buana Malang memiliki kreativitas yang cukup tinggi pada pembelajaran Bahasa Indonesia. Salah satunya ditunjukkan oleh banyaknya ide-ide yang mereka kemukakan untuk membuat kosakata atau kalimat baru yang diawali oleh huruf-huruf tertentu. Namun, guru tersebut menyatakan bahwa belum mengetahui dan belum pernah mencoba untuk mengukur berpikir kreatif matematis siswasiswi kelas VI SDI Surya Buana Malang. Padahal penting bagi pendidik untuk mengetahui tingkat berpikir kreatif matematis siswa agar masing-masing siswa dapat mengembangkan kreativitasnya secara maksimal, khususnya siswa yang tingkat berpikir kreatif matematisnya rendah dapat dibelajarkan sejak awal di sekolah dasar.

Dalam tulisan ini berpikir kreatif matematis merupakan berpikir kreatif dalam memecahkan masalah matematika yaitu berupa masalah openended, dimana berpikir kreatif didefinisikan sebagai kemampuan menghasilkan ide-ide atau gagasan yang melibatkan aspek kefasihan, keluwesan atau keaslian. Indikator kefasihan sebagai berikut. Siswa memiliki banyak ide, jawaban, atau penyelesaian terhadap masalah yang diberikan. Siswa dapat melihat dengan cepat kesalahan atau kekurangan pada jawaban atau penyelesaian yang telah diberikan. Indikator keluwesan sebagai berikut. Siswa memiliki ide, jawaban atau penyelesaian yang bervariasi terhadap masalah yang diberikan. Siswa menerapkan suatu konsep dengan cara atau pendekatan yang berbeda. Indikator keaslian sebagai berikut. Siswa memiliki ide, jawaban, atau penyelesaian yang berbeda (unik), tidak biasa dari siswa seusianya. Siswa menggunakan cara baru dalam menyelesaikan masalah berdasarkan modifikasi (mengembangkan) cara yang lama.

Jawaban-jawaban atau penyelesaian-penyelesain dalam memecahkan masalah mate-matika open-ended yang dihasilkan oleh siswa tidak harus benar akan tetapi harus sesuai dengan perintah soal yang diajukan pada lembar pemecahan masalah. Hal ini didasarkan pada pendapat Eldredge (2011) bahwa aspek kreativitas yang utama tidak hanya 
memuat keaslian tetapi juga kesesuaian (appropriatness). Arti sesuai disini, tidak berarti harus tepat, tetapi dapat dijadikan solusi yang tepat (berguna). Oleh karena itu, munculnya aspek-aspek berpikir kreatif siswa ditentukan berdasarkan kesesuaian jawaban atau penyelesaian dengan masalah yang diberikan.

Dalam rangka mengidentifikasi berpikir kreatif matematis siswa, masalah yang diberikan haruslah masalah yang memberikan kebebasan kepada siswa untuk mengeluarkan gagasangagasan atau ide-ide baru. Siswa harus dilibatkan dengan tugas-tugas yang memberikan mereka ruang untuk bereksplorasi dan mengalami kegiatan kreatif secara matematika (Nadjafikhah, et al, 2011; Svecová, et al, 2014). Masalah-masalah yang menunjang dan mengevaluasi kreativitas matematika dapat berbentuk masalah multiple solution atau yang bersifat terbuka (Sriraman, 2009; Mahmudi, 2010; Leikin, 2013). Masalah yang memenuhi kriteria tersebut adalah masalah open-ended.

Masalah open-ended adalah masalah yang menyajikan suatu permasalahan yang memiliki lebih dari satu jawaban benar atau memiliki lebih dari satu metode penyelesaian yang benar (Shimada, 2005; Levenson, 2013). Penggunaan masalah dengan berbagai solusi atau berbagai pendekatan sangat berguna bagi siswa agar siswa memiliki fleksibilitas pengetahuan dan mampu memecahkan masalah yang masih asing bagi dirinya (Zalenskiy, 2013). Dengan kata lain, masalah openended memberikan kesempatan kepada siswa untuk memperoleh pengetahuan/pengalaman dalam menemukan, mengenali, dan memecahkan masalah dengan berbagai teknik dan strategi penyelesaian.

Penekanan open-ended bukan terletak pada jawaban akhir, melainkan pada upaya dan proses untuk memperoleh jawaban yang benar (Shimada, 2005), sehingga siswa dapat memahami bahwa proses penyelesaian masalah sama pentingnya dengan hasil akhir yang diperoleh. Dengan masalah open-ended siswa dapat mengembangkan pola pikir dan kreativitas mereka sesuai dengan minat dan kemampuannya masing-masing (Ciltas, 2012). Tujuannya tidak lain adalah agar berpikir siswa dapat berkembang secara maksimal dan pada saat yang sama kegiatan-kegiatan kreatif dari setiap siswa terkomunikasikan melalui pemecahan masalah.
Salah satu faktor yang mempengaruhi berpikir kreatif adalah gender. Secara teoritis, ada tidaknya pengaruh perbedaan gender terhadap kemampuan berpikir kreatif masih menjadi isu kontroversial di kalangan peneliti. Hal ini karena hasil pengukuran berpikir kreatif berdasarkan gender tidak ada yang konsisten. Beberapa studi mengungkap bahwa tidak ada perbedaan kemampuan berpikir kreatif yang signifikan jika ditinjau berdasarkan gender (Potur \& Borkul, 2009; Hall, 2009; Roue, 2011; Tabrizi, \& Yaacob, 2011; Sayed \& Mohamed, 2013), tetapi beberapa penelitian lain menemukan bahwa terdapat perbedaan yang signifikan antara level kreatif perempuan dan laki-laki (Baer \& Kaufman, 2008; Kousoulas \& Mega, 2009; Baran, et al, 2011; Al-Srour \& Al-Oweidi, 2013). Oleh karena itu, kajian lebih lanjut sangat diperlukan untuk mengetahui gambaran berpikir kreatif matematis siswa berdasarkan gender. Berdasarkan latar belakang di atas, tujuan penelitian ini mengkaji asesmen pemecahan masalah open-ended untuk mengukur profil berpikir kreatif matematis siswa dan mengkaji profil berpikir kreatif matematis siswa berdasar gender menggunakan asesmen pemecahan masalah open-ended.

\section{METODE}

Penelitian ini merupakan penelitian kualitatif. Dalam penelitian ini asesmen pemecahan masalah open-ended berupa lembar-lembar pemecahan masalah open-ended dan pedoman wawancara untuk mengukur profil berpikir kreatif matematis siswa. Setiap lembar pemecahan masalah openended berisi satu masalah open-ended beserta lembar jawabannya berupa kertas berpetak (kertas grafik). Masalah open-ended yang digunakan memiliki dua kriteria yaitu memiliki banyak cara atau strategi penyelesaian dan memiliki banyak jawaban benar. Gambar 1 menunjukkan Lembar Pemecahan Masalah Open-Ended. Instrumen pedoman wawancara ini berisi garis besar pertanyaan-pertanyaan yang digunakan sebagai acuan pada waktu proses wawancara dengan subjek penelitian atau disebut juga dengan rambu-rambu pertanyaan. Pertanyaan selanjutnya yang diajukan pada saat wawancara akan disesuaikan dengan jawaban-jawaban siswa atau subjek penelitian.

Lembar pemecahan masalah open-ended ini diimplementasikan di SDI Islam Surya Buana yang 
berlokasi di Jalan Simpang Gajayana Malang bagi siswa kelas VI semester ganjil Tahun Pelajaran 2015/2016. Kelas tersebut memiliki tiga rombel yaitu kelas VIA, VIB, dan VIC. Siswa kelas VIA berjumlah enam belas orang terdiri dari enam lakilaki dan sepuluh perempuan. Siswa kelas VIB sebanyak dua puluh tujuh orang terdiri dari enam belas laki-laki dan sebelas perempuan. Sedangkan kelas VIA sebanyak orang terdiri dari lima belas laki-laki dan dua belas perempuan.

Subjek dalam penelitian ini ditentukan berdasarkan hasil kegiatan pemecahan masalah openended dan wawancara. Hasil pemecahan masalah open-ended seluruh siswa kelas VI SDI Surya Buana Malang dianalisis dan dikelompokkan menjadi dua, yaitu siswa yang tidak memenuhi aspek berpikir kreatif matematis dan siswa yang memenuhi minimal satu aspek berpikir kreatif matematis. Siswa yang memenuhi salah satu aspek berpikir kreatif matematis akan dijadikan calon subjek untuk diwawancarai secara mendalam. Berdasarkan analisis lembar pemecahan masalah dan hasil wawancara, calon subjek akan dikelompokkan dalam kategori berpikir kreatif matematis tinggi, sedang dan rendah. Kategori berpikir kreatif matematis siswa dilihat berdasarkan aspek berpikir kreatif matematis yang muncul, yaitu kefasihan, keluwesan, atau keaslian. Wawancara yang akan dilakukan merupakan wawancara semi terstruktur yaitu pertanyaan yang akan diajukan pada saat wawancara disesuaikan dengan jawabanjawaban siswa. Berdasarkan kategori berpikir kreatif matematis tinggi, sedang dan rendah dipilih enam subjek penelitian dengan klasifikasi yaitu tiga siswa laki-laki (satu siswa mewakili berpikir kreatif matematis tinggi, satu siswa mewakili berpikir kreatif sedang, dan satu siswa mewakili berpikir kreatif rendah) dan tiga siswa perempuan (satu siswa mewakili berpikir kreatif matematis tinggi, satu siswa mewakili berpikir kreatif sedang, dan satu siswa mewakili berpikir kreatif rendah). Pemilihan subjek penelitian juga mempertimbangkan kemampuan siswa dalam berkomunikasi.

\section{HASIL}

Data hasil penelitian yang diperoleh dari kegiatan pemecahan masalah open-ended dan wawancara dari masing-masing subjek penelitian dianalisis dan dideskripsikan secara kualitatif. Analisis tersebut dilakukan berdasarkan aspek berpikir kreatif matematis yang muncul yaitu kefasihan, keluwesan, atau keaslian pada pemecahan masalah open-ended yang diberikan oleh subjek penelitian. Untuk melihat profil berpikir kreatif matematis siswa berdasarkan gender, maka dipilih enam subjek penelitian yang terdiri dari tiga siswa laki-laki dan tiga siswa perempuan. Tiga siswa laki-laki dan tiga siswa perempuan tersebut masing-masing mewakili kategori berpikir kreatif matematis tinggi, sedang, dan rendah.

Siswa laki-laki kategori berpikir kreatif matematis tinggi, sedang, dan rendah mengawali langkah penyelesaian yang sama, yaitu memahami masalah menentukan luas bangun datar pada soal. Untuk menghitung luas bangun datar pada soal, siswa laki-laki memiliki cara yang berbeda-beda. Siswa kategori berpikir kreatif matematis tinggi dan rendah menggunakan rumus masing-masing

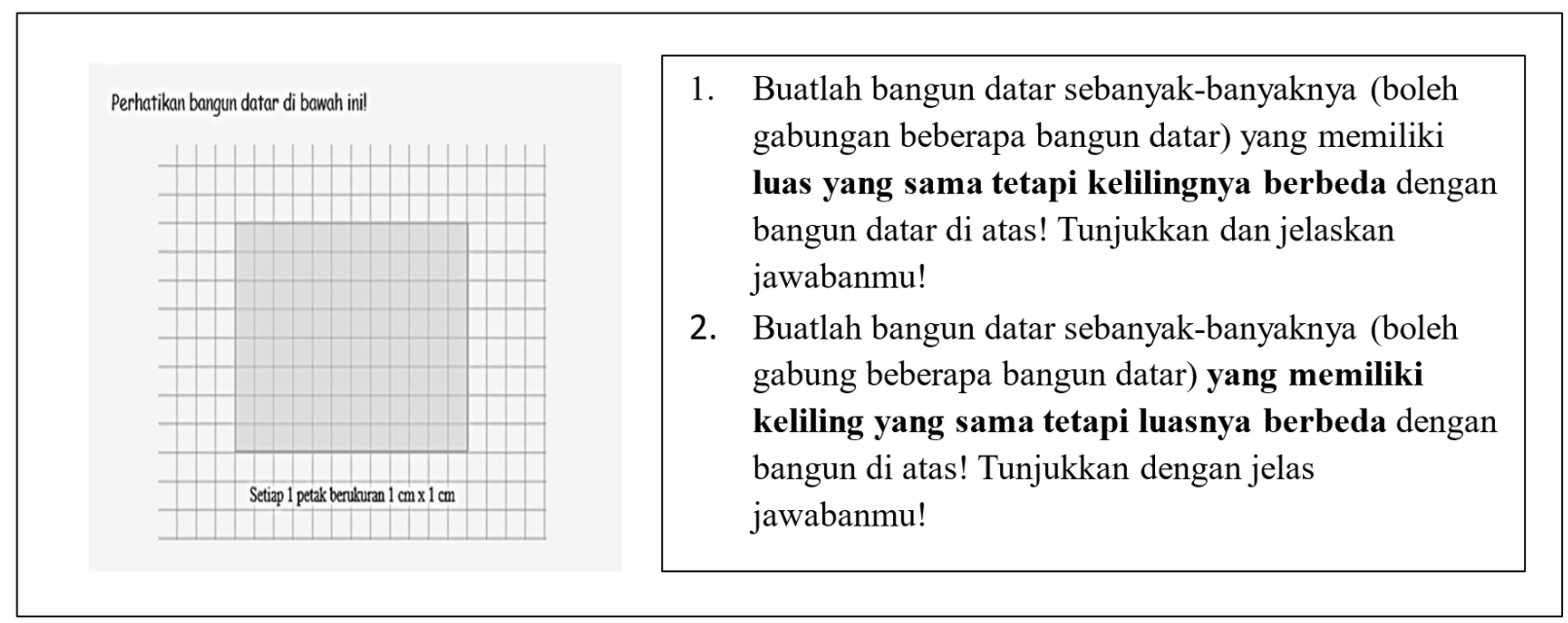

Gambar 1 Lembar Pemecahan Masalah Open-Ended 


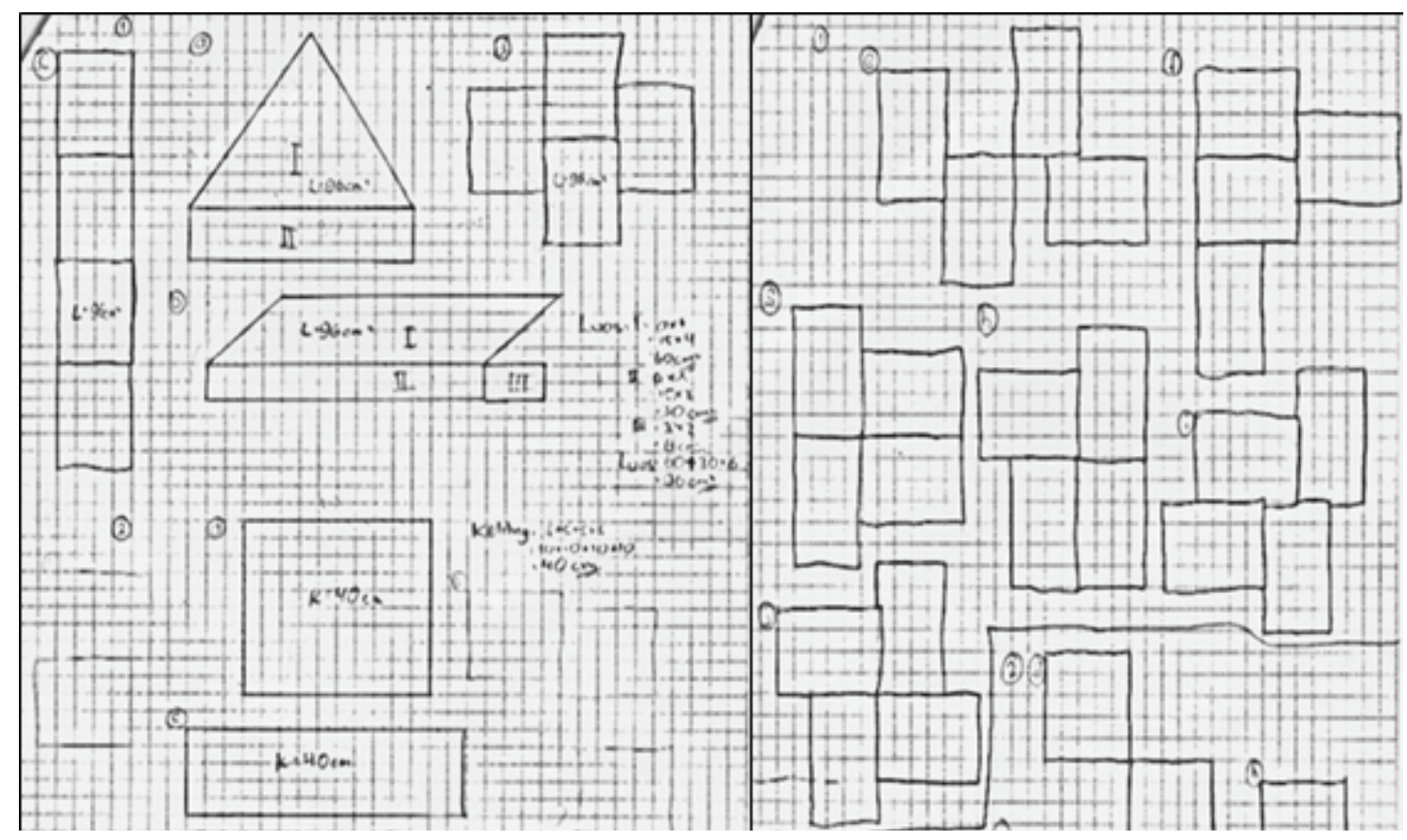

Gambar 2 Contoh Penyelesaian yang diberikan oleh Siswa Laki-laki

luas bangun datar yang disajikan pada lembar pemecahan masalah. Sementara untuk siswa lakilaki kategori berpikir kreatif matematis sedang dengan menghitung banyaknya persegi satuan yang menutupi bangun datar.

Langkah yang dilakukan oleh siswa laki-laki yang memiliki kreativitas matematis selanjutnya yaitu setelah menghitung luas bangun datar pada soal terdapat perbedaan. Siswa laki-laki kategori berpikir kreatif matematis sedang dan rendah menghitung keliling bangun datar pada soal dan kemudian menentukan bangun datar yang akan dibuat. Sementara siswa laki-laki kategori berpikir kreatif matematis tinggi pada salah satu pemecahan masalah menentukan bangun datar yang akan dibuat terlebih dahulu, setelah itu baru menentukan keliling bangun datar pada soal.

Keliling bangun datar pada soal dihitung menggunakan rumus keliling persegi panjang dan menjumlahkan banyak persegi satuan yang mengelilingi sisi bangun datar. Siswa laki-laki kategori berpikir kreatif matematis tinggi dan rendah menghitung keliling bangun datar pada soal menggunakan rumus luas bangun datar. Sementara siswa laki-laki kategori berpikir kreatif matematis sedang menghitung keliling bangun datar pada soal dengan menjumlahkan banyak persegi satuan yang mengelilingi sisi bangun datar.
Pola yang ditemukan pada siswa laki-laki kategori berpikir kreatif matematis tinggi, sedang, dan rendah setelah menghitung luas dan keliling bangun datar pada soal adalah menentukan bangun datar yang akan dibuat beserta ukurannya dan kemudian membuat atau menggambar bangun datar tersebut. Siswa laki-laki kategori berpikir kreatif matematis tinggi, sedang, dan rendah memenuhi aspek berpikir kreatif matematis pada langkah membuat bangun datar yang relevan dengan perintah soal. Berikut adalah contoh bangun datar yang dibuat oleh siswa laki-laki sebagai penyelesaian masalah open-ended (lihat gambar 2).

Siswa laki-laki kategori berpikir kreatif matematis tinggi memenuhi ketiga aspek berpikir kreatif matematis ketika membuat bangun datar yang digunakan sebagai pemecahan masalah. Munculnya aspek kelancaran ditandai dengan banyaknya ide atau penyelesaian yang diberikan oleh siswa lakilaki kategori berpikir kreatif matematis tinggi dengan membuat banyak bangun datar yang relevan dengan perintah soal. Munculnya aspek keluwesan ditandai dengan beragam ide atau penyelesaian yang diberikan oleh siswa laki-laki kategori berpikir kreatif matematis tinggi dengan membuat bangun datar yang yang bervariasi. Munculnya aspek keluwesan juga ditandai oleh kemampuannya menggunakan suatu konsep dengan sudut pandang 
yang berbeda. Munculnya aspek keaslian pada pemecahan yang diberikan oleh siswa laki-laki kategori berpikir kreatif matematis tinggi ditandai dengan cara unik yang dicetuskannya. Siswa lakilaki kategori berpikir kreatif matematis tinggi menggunakan konsep trasformasi untuk membuat bangun datar baru yang bentuknya berbeda tanpa harus menghitung luasnya, karena luasnya sudah diketahui dari bangun datar yang sebelumnya telah dibuat.

Siswa laki-laki kategori berpikir kreatif matematis sedang memenuhi dua aspek berpikir kreatif matematis yaitu aspek kelancaran dan keluwesan dalam membuat bangun datar yang digunakan sebagai pemecahan masalah. Munculnya aspek kelancaran ditandai dengan banyaknya ide atau penyelesaian yang diberikan oleh siswa lakilaki kategori berpikir kreatif matematis sedang dengan menggunakan banyak cara penyelesaian dan membuat banyak bangun datar yang relevan dengan perintah soal. Munculnya aspek keluwesan ditandai dengan beragam ide atau penyelesaian yang diberikan oleh siswa laki-laki kategori berpikir kreatif matematis tinggi dengan membuat bangun datar yang yang bervariasi dan juga cara yang bervariasi.

Siswa laki-laki kategori berpikir kreatif matematis rendah hanya memenuhi salah satu aspek berpikir kreatif matematis yaitu aspek kelancaran dalam membuat bangun datar yang digunakan sebagai pemecahan masalah. Munculnya aspek kelancaran ditandai dengan banyaknya ide atau penyelesaian yang diberikan oleh siswa laki-laki kategori berpikir kreatif matematis sedang dengan membuat banyak bangun datar yang relevan dengan perintah soal.

Berikut adalah contoh struktur berpikir kreatif matematis siswa laki-laki dalam memecahkan masalah open-ended (lihat gambar 3).

Siswa perempuan kategori berpikir kreatif matematis tinggi, sedang, dan rendah mengawali langkah penyelesaian yang sama, yaitu memahami masalah menentukan luas bangun datar pada soal. Untuk menghitung luas bangun datar pada soal, siswa perempuan juga memiliki cara yang sama. Siswa perempuan kategori berpikir kreatif matematis tinggi, sedang, dan rendah menggunakan rumus luas bangun datar sesuia dengan bangun datar yang disajikan pada lembar pemecahan masalah.
Setelah menghitung luas dan keliling bangun datar pada soal, siswa perempuan kategori berpikir kreatif matematis tinggi, sedang, dan rendah melakukan langkah yang sama kembali. Mereka sama-sama menentukan bangun datar yang akan dibuat. Bangun datar yang dibuat akan disesuaikan dengan perintah soal yaitu membuat bangun datar yang luasnya sama tetapi kelilingnya berbeda dan membuat bangun datar yang luasnya berbeda tetapi kelilingnya sama.

Langkah pemecahan masalah selanjutnya yang dilakukan oleh siswa perempuan kategori berpikir kreatif matematis tinggi, sedang, dan rendah setelah menentukan bangun datar yang dibuat memiliki perbedaan. Siswa perempuan kategori berpikir kreatif matematis tinggi menentukan keliling bangun datar yang akan dibuat terlebih dahulu pada salah satu pemecahan masalah, menentukan ukurannya agar luasnya sama, dan terakhir membuat gambar bangun datar. tersebut. Namun, untuk pemecahan yang lain, siswa perempuan kategori berpikir kreatif matematis tinggi menentukan ukuran sisi bangun datar yang akan dibuat dan kemudian membuat gambarnya. Sementara, yang dilakukan oleh siswa perempuan kategori berpikir kreatif matematis sedang dan rendah setelah adalah menghitung luas dan keliling bangun datar pada soal menentukan ukuran sisi bangun datar yang akan dibuat dan kemudian membuat gambarnya. Berikut adalah contoh bangun datar yang dibuat oleh siswa perempuan sebagai penyelesaian masalah openended (lihat gambar 4).

Siswa perempuan kategori berpikir kreatif matematis tinggi memenuhi aspek keluwesan dan originality dalam menentukan keliling bangun datar yang akan dibuat. Munculnya aspek keluwesan ditandai oleh kemampuan siswa berpikir kreatif matematis tinggi menggunakan suatu konsep dengan sudut pandang atau cara yang berbeda dengan cara siswa perempuan kategori berpikir kreatif matematis tinggi yang menerapkan rumus keliling agar terpenuhi syarat bangun datar yang memiliki keliling berbeda sekaligus juga memiliki luas yang sama.

Siswa perempuan kategori berpikir kreatif matematis tinggi memenuhi aspek berpikir kreatif matematis kelancaran ketika membuat bangun datar yang digunakan sebagai pemecahan masalah. Munculnya aspek kelancaran ditandai dengan 


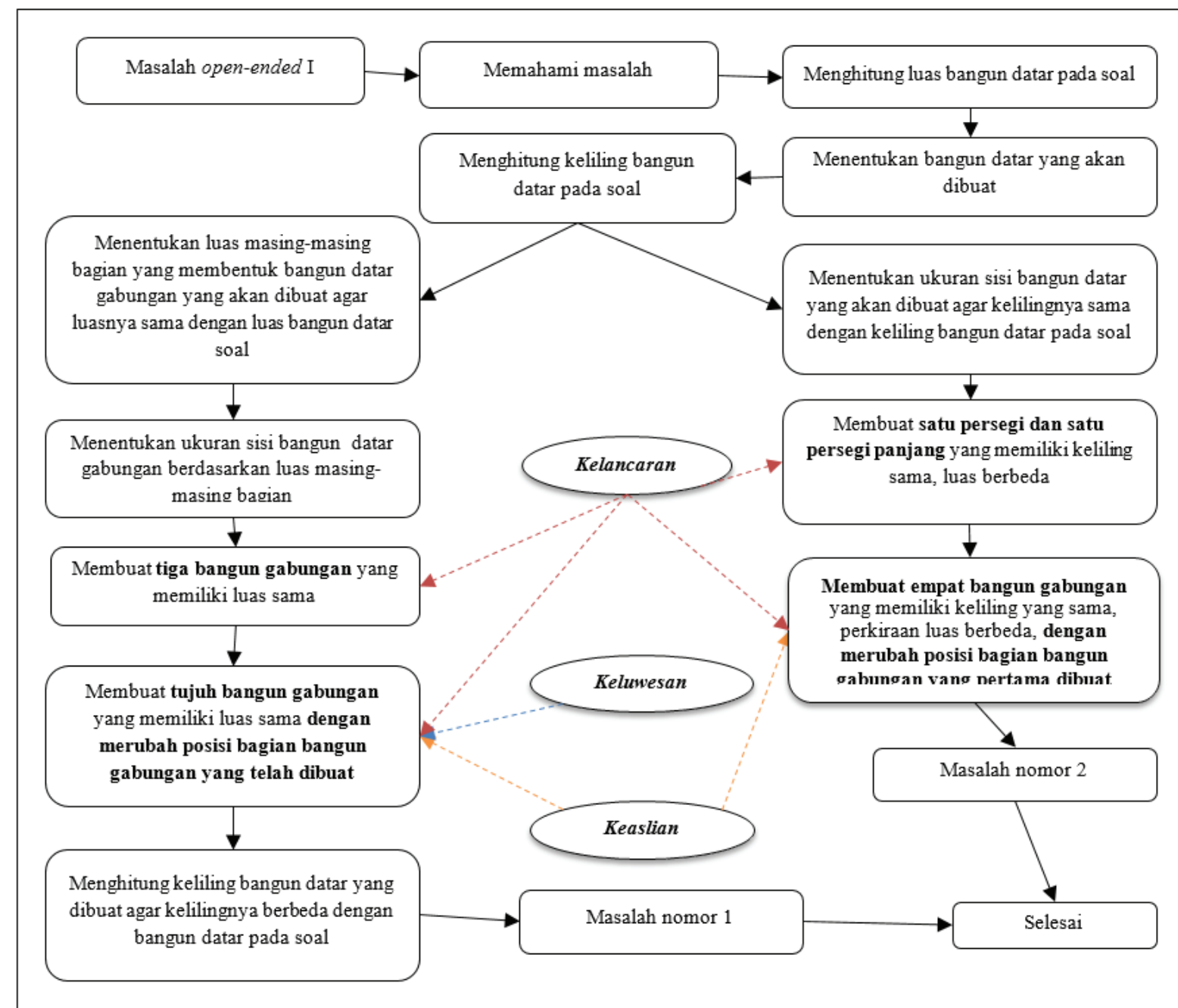

\section{Keterangan gambar:}

$\begin{array}{lll}=\text { Muncul kelancaran } & \text { Muncul keluwesan } & \text { Muncul keaslian } \\ = & \text { Ada kesalahan }\end{array}$

Gambar 3 Contoh Struktur Berpikir Kreatif Matematis Siswa Laki-laki dalam Pemecahan Masalah Open-Ended

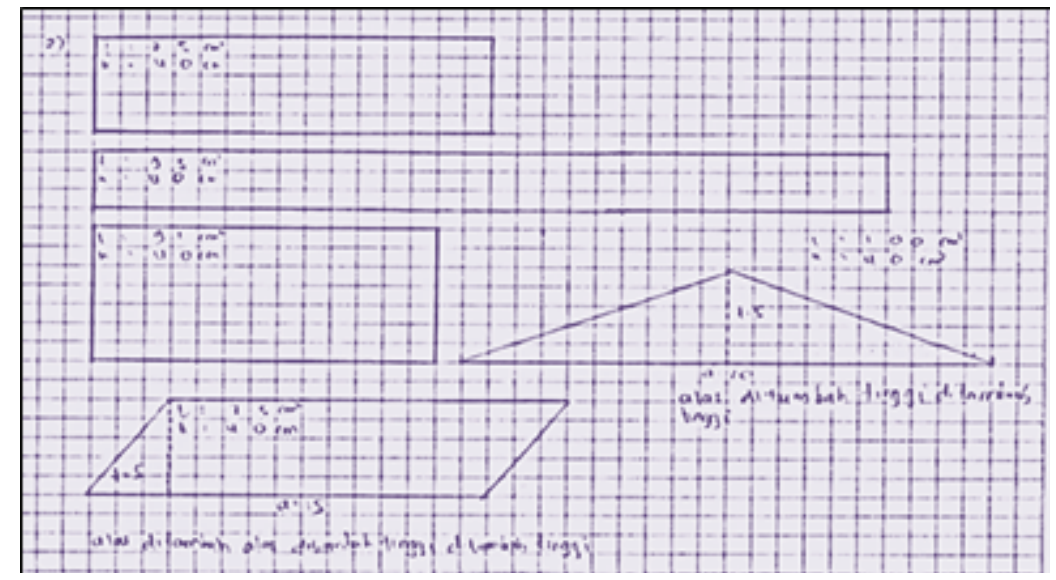

Gambar 4 Contoh Penyelesaian yang Diberikan oleh Siswa Perempuan 
banyaknya ide atau penyelesaian yang diberikan oleh siswa perempuan kategori berpikir kreatif matematis tinggi dengan membuat banyak bangun datar yang relevan dengan perintah soal.

Siswa perempuan kategori berpikir kreatif matematis sedang memenuhi dua aspek berpikir kreatif matematis yaitu aspek kelancaran dan keluwesan dalam membuat bangun datar yang digunakan sebagai pemecahan masalah. Munculnya aspek kelancaran ditandai dengan banyaknyaideatau penyelesaian yang diberikan oleh siswa perempuan kategori berpikir kreatif matematis sedang dengan membuat banyak bangun datar yang relevan dengan perintah soal dan kemampuan melihat kesalahan atau kekurangan pada penyelesaian yang diberikan. Munculnya aspek keluwesan ditandai dengan beragam ide atau penyelesaian yang diberikan oleh siswa perempuan kategori berpikir kreatif matematis sedang dengan membuat bangun datar yang bervariasi atau beragam.

Siswa perempuan kategori berpikir kreatif matematis rendah hanya memenuhi salah satu aspek berpikir kreatif matematis yaitu aspek kelancaran dalam membuat bangun datar yang dijadikan penyelesaian. Munculnya aspek kelancaran ditandai dengan banyaknya ide atau penyelesaian yang diberikan oleh siswa perempuan kategori berpikir kreatif matematis rendah dengan membuat banyak bangun datar yang relevan dengan perintah soal.

Berikut adalah contoh struktur berpikir kreatif matematis siswa perempuan dalam memecahkan masalah open-ended (lihat gambar 5).

\section{PEMBAHASAN}

Hasil temuan menunjukkan bahwa ketika dikonfirmasi mengenai kebenaran jawaban yang mereka berikan, siswa laki-laki kategori berpikir kreatif matematis tinggi, sedang, dan rendah merasa yakin dan tidak menyadari kesalahan yang dilakukannya. Dalam hal ini siswa laki-laki kategori berpikir kreatif matematis tinggi, sedang, ataupun rendah tidak memenuhi salah satu indikator berpikir kreatif matematis kelancaran, yaitu melihat dengan cepat kesalahan atau kekurangan pada pemecahan yang diberikan. Merujuk pada studi Arend (2007) yang menyatakan bahwa siswa laki-laki lebih memiliki rasa percaya diri dan cenderung menilai kinerjanya lebih positif jika dibandingkan dengan siswa perempuan, maka dapat dikatakan penelitian ini berbanding lurus terhadap studi tersebut.
Siswa laki-laki berpikir kreatif tinggi, sedang, dan rendah tidak menyadari kekeliruannya dalam menyelesaikan masalah karena sudah yakin dan optimis dengan jawaban yang diberikan. Hal ini menunjukkan bahwa siswa laki-laki memiliki rasa percaya diri yang tinggi dalam menyelesaikan masalah.

Setelah menghitung luas bangun datar pada soal, siswa perempuan kategori berpikir kreatif matematis tinggi, sedang, dan rendah menghitung keliling bangun datar pada soal. Cara yang digunakan oleh siswa perempuan kategori berpikir kreatif matematis tinggi, sedang dan rendah semuanya sama. Mereka menghitung keliling bangun datar menggunakan rumus keliling bangun datar. Kemampuan siswa perempuan kategori berpikir kreatif matematis tinggi, sedang, dan rendah untuk melihat kekurangan atau kesalahan pada pemecahan masalah yang diberikan menunjukkan bahwa siswa perempuan cenderung untuk berhati-hati dan tidak berani mengambil resiko jika penyelesaian yang diberikan salah. Hal ini karena siswa perempuan cenderung lebih peduli terhadap prestasi belajar mereka disekolah (Arend, 2008). Sehingga, ketika dikonfirmasi mengenai jawaban pemecahan masalah yang diberikan, mereka berusaha melihat kembali pekerjaannya dengan detail agar tidak menghasilkan jawaban yang keliru.

Profil berpikir kreatif matematis siswa ditinjau berdasarkan gender memiliki persamaan dan perbedaan. Persamaan profil berpikir kreatif matematis mereka ditunjukkan oleh aspek berpikir kreatif matematis yang muncul pada masing-masing kategori kreativitas dalam memecahkan masalah. Sementara, perbedaan profil berpikir kreatif matematis berdasarkan gender ditunjukkan oleh cara berpikir siswa laki-laki dan siswa perempuan kategori berpikir kreatif matematis tinggi dan indikator aspek kelancaran yang muncul pada siswa laki-laki dan siswa perempuan pada semua kategori.

Persaamaan siswa laki-laki dan siswa perempuan kategori berpikir kreatif matematis tinggi yaitu memenuhi aspek kelancaran, keluwesan, dan keaslian pada pemecahan masalah open-ended. Aspek berpikir kreatif matematis yang muncul pada siswa laki-laki dan siswa perempuan kategori berpikir kreatif matematis sedang yaitu kelancaran dan keluwesan. Aspek berpikir kreatif matematis yang muncul pada siswa laki-laki dan siswa perempuan kategori berpikir kreatif matematis rendah juga 


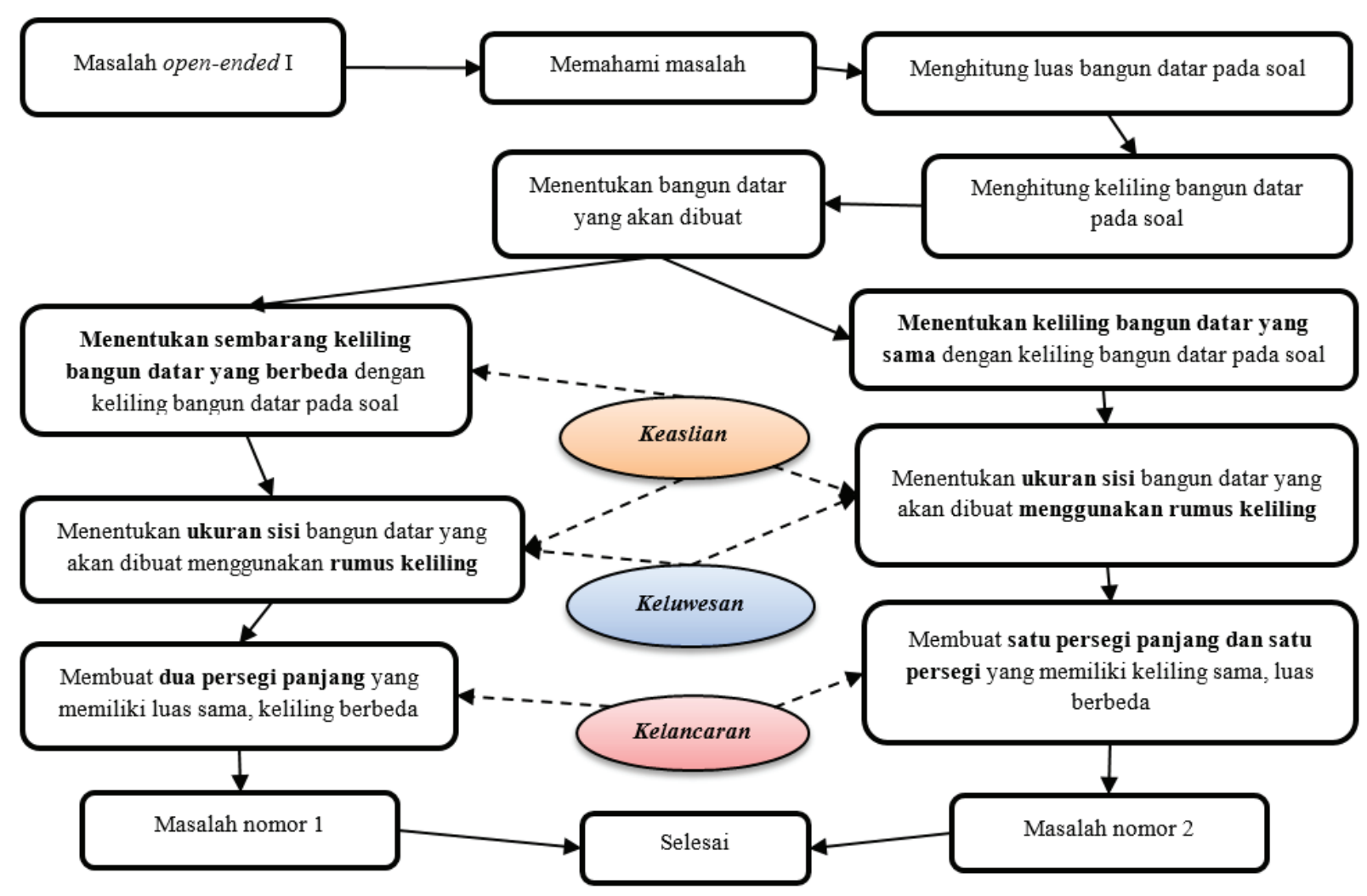

Keterangan gambar:

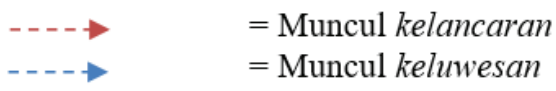

$\quad=$ Muncul keastian

Gambar 5 Struktur Berpikir Kreatif Matematis Siswa Perempuan dalam Pemecahan Masalah Open-Ended

sama, yaitu hanya menunjukkan aspek kelancaran.

Meskipun kuantitas munculnya aspek kelancaran dan keluwesan pada pemecahan masalah open-ended yang diberikan oleh siswa laki-laki dan siswa perempuan kategori berpikir kreatif matematis tinggi adalah sama, namun secara kualitas berbeda. Siswa siswa perempuan kategori berpikir kreatif matematis tinggi memenuhi kedua indikator untuk masing-masing aspek kelancaran dan keluwesan. Sementara siswa laki-laki kategori berpikir kreatif matematis tinggi hanya memenuhi salah satu indikator untuk masing-masing aspek kelancaran dan keluwesan.

Berdasarkan indikator yang muncul, siswa laki-laki dan siswa perempuan kategori berpikir kreatif matematis sedang sama-sama menunjukkan salah satu indikator keluwesan, tetapi tidak dengan indikator kelancaran. Siswa perempuan kategori berpikir kreatif matematis sedang memenuhi kedua indikator aspek kelancaran. Sementara siswa laki-laki kategori berpikir kreatif matematis sedang hanya memenuhi salah satu indikator aspek kelancaran.

Dalam hal munculnya indikator kelancaran, siswa laki-laki dan siswa perempuan kategori berpikir kreatif matematis rendah juga memiliki perbedaan. Siswa perempuan kategori berpikir kreatif matematis rendah memenuhi kedua indikator aspek kelancaran. Sementara siswa laki-laki kategori berpikir kreatif matematis rendah hanya memenuhi salah satu indikator aspek kelancaran.

Jika ditelusuri berdasarkan aspek-aspek yang muncul, maka siswa laki-laki dan siswa perempuan tidak memiliki perbedaan pada kemampuan berpikir kreatif matematis mereka. Hal ini bertentangan dengan penelitian-penlitian sebelumnya yang mengungkapkan adanya perbedaan signifikan antara kreativitas matematis siswa laki-laki dan siswa perempuan (Baer \& Kaufman, 2008; Kousoulas \& Mega, 2009; Baran, et al, 2011; Al- 
Srour \& Al-Oweidi, 2013). Namun, jika ditelusuri berdasarkan indikator-indikator yang muncul dari setiap aspek berpikir kreatf matematis dan cara berpikir siswa laki-laki dan siswa perempuan sehingga mendapatkan ide-ide-yang unik untuk menyelsaikan masalah maka ada perbedaan diantara keduanya.

Secara umum perbedaan berpikir kreatif matematis berdasarkan gender pada pemecahan masalah open-ended terletak pada aspek kelancaran. Perbedaan dilihat berdasarkan indikator yang muncul. Siswa perempuan memenuhi kedua indikator aspek kelancaran yaitu memiliki banyak ide, jawaban, atau penyelesaian terhadap masalah yang diberikan dan melihat dengan cepat kesalahan atau kekurangan terhadapat penyelesaian yang telah diberikan. Sementara laki-laki, hanya memenuhi salah satu indikator saja yaitu memiliki banyak ide, jawaban, atau penyelesaian terhadap masalah yang diberikan. Jadi, perbedaannya terletak pada kemampuan untuk melihat kesalahan atau kekurangan yang dilakukan, bukan pada banyaknya ide-ide yang dihasilkan. Hal ini bertentangan dengan hasil temuan Kousulas dan Mega (2009) dan Hall (2009) yang menunjukkan bahwa siswa perempuan menghasilkan lebih banyak ide atau penyelesaian daripada anak laki-laki.

Berdasarkan tabel 1 dapat ditunjukkan aspekaspek berpikir kreatif matematis yang muncul pada siswa berdasarkan gender dalam memecahkan masalah open-ended I, II, dan III.
Perbedaan dari cara berpikir kreatif matematis paling menonjol ditemukan pada siswa laki-laki dan siswa perempuan kategori berpikir kreatif matematis tinggi. Siswa laki-laki kategori berpikir kreatif matematis tinggi memiliki kemampuan visual spasial yang tinggi, sementara siswa perempuan kategori berpikir matematis tinggi memiliki penalaran matematis yang tinggi. Hal ini ditunjukkan siswa laki-laki kategori berpikir kreatif matematis tinggi yang membayangkan bentuk yang berbeda-beda dari suatu objek (bangun datar) hanya dengan melakukan translasi atau rotasi objek tersebut. Sementara siswa perempuan kategori berpikir kreatif matematis tinggi yang menggunakan sembarang keliling suatu bangun datar yang akan dibuat untuk mendapatkan luas bangun datar yang sama namun kelilingnya berbeda dengan bangun datar pada soal. Dalam hal ini, siswa perempuan kategori berpikir kreatif matematis tinggi menganalisis sembarang keliling agar mendapatkan ukuran yang sesuai dengan bangun datar yang diinginkan. Kemudian, siswa perempuan kategori berpikir kreatif matematis tinggi memutuskan keliling yang dapat digunakan untuk membuat bangun datar baru. Jadi, perbedaan yang ditemukan pada siswa laki-laki dan siswa perempuan tidak hanya berdasarkan aspek-aspek berpikir kreatif matematis yang muncul, tetapi juga cara berpikir siswa untuk memecahkan masalah secara kreatif.

Tabel 1 Munculnya Aspek-Aspek Berpikir Kreatif Matematis Siswa berdasarkan Gender pada Pemecahan Masalah Open-Ended

\begin{tabular}{|c|c|c|c|c|c|c|c|c|c|c|c|c|c|c|c|c|c|}
\hline \multirow{3}{*}{ 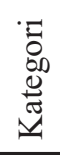 } & \multirow{3}{*}{ 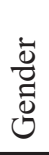 } & \multicolumn{6}{|c|}{ Masalah I } & \multicolumn{6}{|c|}{ Masalah II } & \multicolumn{4}{|c|}{ Masalah III } \\
\hline & & \multicolumn{2}{|c|}{$\mathrm{Fl}$} & \multicolumn{2}{|c|}{$\mathrm{Fx}$} & \multicolumn{2}{|c|}{ Or } & \multicolumn{2}{|c|}{$\mathrm{Fl}$} & \multicolumn{2}{|c|}{$\mathrm{Fx}$} & \multicolumn{2}{|c|}{ Or } & \multicolumn{2}{|c|}{$\mathrm{Fl}$} & $F x$ & Or \\
\hline & & In1 & $\operatorname{In} 2$ & In1 & $\operatorname{In} 2$ & In1 & In2 & In1 & In2 & $\operatorname{In} 1$ & $\operatorname{In} 2$ & In1 & $\operatorname{In} 2$ & In1 & $\operatorname{In} 2$ & In1 In2 & In1 In2 \\
\hline \multirow{2}{*}{$\mathrm{T}$} & $\mathrm{L}$ & $\sqrt{ }$ & & $\sqrt{ }$ & $\sqrt{ }$ & $\sqrt{ }$ & & $\sqrt{ }$ & & $\sqrt{ }$ & $\sqrt{ }$ & $\sqrt{ }$ & & $\sqrt{ }$ & & $\sqrt{ }$ & $\sqrt{ }$ \\
\hline & $\mathrm{P}$ & $\sqrt{ }$ & $\sqrt{ }$ & $\sqrt{ }$ & $\sqrt{ }$ & $\sqrt{ }$ & & $\sqrt{ }$ & & $\sqrt{ }$ & $\sqrt{ }$ & & & $\sqrt{ }$ & $\sqrt{ }$ & $\sqrt{ }$ & \\
\hline \multirow{2}{*}{ S } & $\mathrm{L}$ & $\sqrt{ }$ & & $\sqrt{ }$ & & & & $\sqrt{ }$ & & $\sqrt{ }$ & & & & $\sqrt{ }$ & & $\sqrt{ }$ & \\
\hline & $\mathrm{P}$ & $\sqrt{ }$ & $\sqrt{ }$ & $\sqrt{ }$ & & & & $\sqrt{ }$ & $\sqrt{ }$ & $\sqrt{ }$ & & & & $\sqrt{ }$ & $\sqrt{ }$ & $\sqrt{ }$ & \\
\hline \multirow[b]{2}{*}{$\mathrm{R}$} & $\mathrm{L}$ & $\sqrt{ }$ & & & & & & $\sqrt{ }$ & & & & & & $\sqrt{ }$ & & & \\
\hline & $\mathrm{P}$ & $\sqrt{ }$ & $\sqrt{ }$ & & & & & $\sqrt{ }$ & $\sqrt{ }$ & & & & & $\sqrt{ }$ & $\sqrt{ }$ & & \\
\hline
\end{tabular}

Keterangan:

$\mathrm{T}=$ Berpikir kreatif matematis tinggi

$\mathrm{S}=$ Berpikir kreatif matematis sedang

$\mathrm{R}=$ Berpikir kreatif matematis rendah

$\mathrm{L}=$ Siswa laki-laki

$\mathrm{P}=$ Siswa perempuan
$\mathrm{Fl}=$ Muncul kelancaran

$\mathrm{Fx}=$ Muncul keluwesan

Or $=$ Muncul keaslian

In $1=$ Memenuhi indikator 1

In $2=$ Memenuhi inikator 2 
Temuan menunjukkan bahwa berpikir kreatif matematis laki-laki kategaori tinggi dipengaruhi oleh kemampuan visual spasial yang mereka miliki. Hal ini sesuai dengan hasil studi Maccoby dan Jacklin (Burr, 2002) yang menyatakan bahwa secara umum kemampuan visual spasial laki-laki lebih baik dari pada perempuan. Dengan kemampuan visual spasial yang baik, mudah bagi siswa lakilaki untuk menyelesaikan masalah terkait dengan membuat bangun datar yang luasnya sama tetapi kelilingnya berbeda dengan bangun datar pada soal atau sebaliknya.

Untuk siswa perempuan ketegori berpikir kreatif matematis tinggi, temuan penelitian mengungkap bahwa berpikir kreatif matematis mereka dipengaruhi oleh kemampuan menalar. Hal ini didasarkan pada cara berpikir siswa perempuan ketegori berpikir kreatif matematis tinggi, yaitu menggunakan pemikiran yang logis dan analitis dalam menyelesaikan masalah. Karena penalaran merupakan proses berpikir siswa dengan karakteristik berpola pikir logis dan bersifat analitis (Subanji, 2011). Dengan demikian, hasil studi Maccoby dan Jacklin (Burr, 2002) dan Santrock (2013) yang menyatakan siswa laki-laki lebih baik daripada perempuan darisegi kemampuan metematika tidak sepenuhnya benar. Temuan penelitian ini menunjukkan siswa perempuan tidak hanya lebih baik dalam kemampuan verbal saja tetapi juga halhal yang berkaitan dengan kemampuan matematika dan kemampuan menalar secara matematis.

\section{SIMPULAN DAN SARAN}

\section{Simpulan}

Asesmen pemecahan masalah open-ended berupa lembar-lembar pemecahan masalah openended dan pedoman wawancara untuk mengukur profil berpikir kreatifmatematis siswa. Setiap lembar pemecahan masalah open-ended berisi satu masalah open-ended beserta lembar jawabannya berupa kertas berpetak (kertas grafik). Masalah openended yang digunakan memiliki dua kriteria yaitu memiliki banyak cara atau strategi penyelesaian dan memiliki banyak jawaban benar.

Profil berpikir kreatif matematis siswa berdasarkan gender dalam pemecahan masalah openended sebagai berikut. Siswa laki-laki dan siswa perempuan kategori berpikir kreatif matematis tinggi memenuhi tiga aspek berpikir kreatif matematis, yaitu aspek kelancaran, keluwesan, dan keaslian dalam memecahkan masalah open-ended. Siswa laki-laki dan siswa perempuan kategori berpikir kreatif matematis sedang memenuhi dua aspek berpikir kreatif matematis, yaitu aspek kelancaran dan keluwesan. Sedangkan siswa laki-laki dan siswa perempuan kategori berpikir kreatif matematis rendah hanya memenuhi salah satu aspek, yaitu aspek kelancaran.

Perbedaan berpikir kreatif matematis siswa laki-laki dan siswa perempuan ditemukan pada munculnya indikator aspek kelancaran. Dua indikator aspek kelancaran yang digunakan yaitu memiliki banyak ide, jawaban, atau penyelesaian dan kemampuan melihat kesalahan atau kekurangan pada penyelesaian yang telah diberikan. Siswa perempuan menunjukkan kedua indikator tersebut. Sedangkan siswa laki-laki hanya memenuhi salah satu indikator yaitu memiliki banyak ide, jawaban, atau penyelesaian dan kemampuan melihat kesalahan. Artinya, perbedaan profil berpikir kreatif matematis siswa sekolah dasar berdasarkan terletak pada kefasihan siswa untuk melihat kesalahan atau kekurangan pada pemecahan masalah yang diberikan, tetapi tidak dari sisi banyaknya ide, jawaban, atau penyelesaian yang dihasilkan.

Perbedaan dari cara berpikir kreatif matematis paling menonjol ditemukan pada siswa laki-laki dan siswa perempuan kategori berpikir kreatif matematis tinggi. Siswa laki-laki kategori berpikir kreatif matematis tinggi memiliki kemampuan visual spasial yang tinggi, sementara siswa perempuan kategori berpikir matematis tinggi memiliki penalaran matematis yang tinggi, yaitu penalaran induktif. Masing-masing kemampuan yang dimiliki oleh siswa laki-laki dan siswa perempuan kategori berpikir kreatif matematis tinggi menunjang kemampuan berpikir kreatif mereka sehingga menghasilkan ide-ide dan penyelesaian yang unik (keaslian).

\section{Saran}

Berdasarkan hasil temuan dalam penelitian ini, maka saran untuk penelitian selanjutnya adalah perlu dilakukan kajian lebih lanjut tentang asesmen pemecahan masalah open-ended untuk mengukur profil berpikir kreatif matematis siswa berdasarkan gender dengan memperhatikan aspek keaslian dari siswa laki-laki dan siswa perempuan. Hal ini dikarenakan perbedaan berpikir kreatif matematis siswa laki-laki dan siswa perempuan yang paling 
menonjol khususnya kategori tinggi adalah dari segi keunikan atau kebaruan pemecahan masalah yang mereka berikan. Walaupun siswa laki-laki dan siswa perempuan kategori berpikir kreatif matematis tinggi masing-masing memenuhi aspek tersebut, namun munculnya aspek keaslian pada siswa laki-laki dipengaruhi oleh kemampuan visual spasial, sementara munculnya aspek keaslian pada siswa perempuan dipengaruhi oleh kemampuan penalaran matematis.

Hasil temuan dalam penelitian ini diharapkan dapat berimplikasi bagi praktik dunia pendidikan, khususnya pendidikan dasar. Hal tersebut dapat diimplementasikan sebagai bahan pertimbangan atau dasar dalam mengembangkan asesmen dan model pembelajaran, serta media pembelajaran, dalam rangka meningkatkan berpikir kreatif siswa sekolah dasar, khususnya dengan memperhatikan keunikan dari cara berpikir masing-masing siswa.

\section{DAFTAR RUJUKAN}

Al-Srour, N., \& Al-Oweidi, A. 2013. The Level of Creativity among Management Employees, Academic Staff and Artistes and Its Relationship with Gender, Practical Experience and Age. Creative Education, 4 (3), 185-188.

Arend, R. I. 2007. Learning to Teach (7th Ed). New York: McGraw-Hill Higher Educaton.

Baer, J., \& Kaufman, J. C. 2008. Gender Differences in Creativity. Journal of Creative Behavior Second Quarter, 42 (2), 75-105.

Baran, G., Erdogan, S., \& Cakmak, A. 2011. A Study on the Relationship between Six-YearOld Children's Creativity and Mathematical Ability. International Education Studies, 4 (1), 105-111.

Brunkalla. 2009. How to Increase Mathematical Creativity-An Experiment. The Montana Mathematics Enthusiast, 6 (1\&2), 257-266.

Burr, V. 2002. Gender and Social Psychology. London and New York: Routledge.

Chamberlin, S., \& Moon, S. 2005. Model-Eliciting Activities as a Tool to Develop and Identify Creatively Gifted Mathematicians. JSGE: The Journal of Secondary Gifted Education, 17 (1), 37-47.

Ciltas, A. 2012. The Effect of the Mathematical Modelling Method on the Level of Creative Thinking. Education Research Complete, 30 (4), 103-113.
Eldredge, J. 2011. Creativity in Research, Part 2: Classifying Creativity. Hypothesis, 23 (1), 1013.

Hall, L. 2009. Problem Solving and Creativity: A Gender and Grade Level Comparison. New Jersey: ProQuest Dissertation Publishing.

Kousoulas, F., \& Mega, G. 2009. Students' Divergent Thinking and Teachers' Ratings of Creativity: Does Gender Play a Role? Journal of Creative Behavior, 43 (3), 209-222.

Leikin, R. 2013. Evaluating Mathematical Creativity: The Interplay Between Multiplicity and Insight. Psychological Test and Assessment Modeling, 55, (4), 385-400.

Levenson, E. 2013. Tasks that May Occasion Mathematical Creativity: Teachers' Choices. Journal Math Teacher Education, 16, 269-291.

Mahmudi, A. 2010. Mengukur Kemampuan Berpikir Kreatif Matematis. Konferensi Nasional Matematika XV, UNIMA. Manado.

Mann, L. 2009. The Search for Mathematical Creativity: Identifying Creative Potential in Middle School Students. Creativity Research Journal, 21 (4), 338-348.

Nadjafikhah, M., Yaftian, N., \& Bakhshalizadeh, S. 2011. Mathematical Creativity: Some Definitions and Characteristics. ProcediaSocial and Behavioral Sciences, 31, 285-291.

NCTM. 2000. Principles and Standard for School Mathematics. Reston: The National Council of Teachers of Mathematics, Inc.

Potur, A., \& Borkul, O. 2009. Gender and Creative Thinking in Education: A Theoretical and Experimental Overview. ITU A|Z, 6 (2), 44-57.

Roue, L. C. 2011. A Study of Grade Level and Gender Differences in Divergent Thinking among 8 th and 11 th Graders in a Mid-Western School District. Doctoral dissertation. University of Minnesota.

Sa'dijah, C. 2013. Kepekaan Bilangan Siswa SMP Melalui Pembelajaran Kontekstual yang Mengintegrasikan Ketrampilan Berpikir Kreatif. Jurnal Pendidikan dan Pembelajaran, 20 (2), 222-227.

Santrock, J. 2013. Psikologi Pendidikan. Jakarta: Kencana Prenada Media Group.

Sayed, E., \& Mohamed, A. 2013. Gender Differences in Divergent Thinking: Use of the Test of Creative Thinking-Drawing Production on an Egyptian Sample. Creativity Research 
Journal, 25 (2), 222-227.

Sharma, Y. 2014. The Effects of Strategy and Mathematics Anxiety on Mathematical Creativity of School Students. Mathematics Education, 9 (1), 25-37.

Shimada, S. 2005. The Open-Ended Approach: A New Proposal for Teaching Mathematics (J.P. Becker \& S. Shimada, Ed.). Virginia: The National Council of Teachers of Mathematics, Inc.

Siswono, T., \& Rosyidi, A. 2005. Menilai Kreativitas Siswa dalam Matematika. Seminar Nasional Matematika dan Pendidikan Matematika, Jurusan Matematika FMIPA UNESA. Surabaya.

Sriraman, B. 2009. The Characteristics of Mathematical Creativity. ZDM Mathematics Education, 41, 13-27.

Sriraman, B., Haavold, P., \& Lee, K. 2013. Mathematical Creativity and Giftedness: A Commentary on and Review of Theory, New Operational Views, and Ways Forward. ZDM Mathematics Education, 45, 215-225.
Subanji. 2011. Teori Berpikir Pseudo Penalaran Kovariasioa. Malang: Universitas Negeri Malang (UM Press).

Svecová, V., Rumanova, L., \& Pavlovicova, G. 2014. Support of Pupil's Creative Thinking in Mathematical Education. Procedia - Social and Behavioral Sciences, 116, 1715-1719.

Tabrizi, E., M.A., T., \& Yaacob, S. 2011. Relationship Between Creative Thinking and Anxiety Among Adolescent Boys and Girls in Tehran, Iran. International Journal of Humanities and Social Science, 1 (19), 60-66.

Voica, C. 2012. Creative Contexts as Ways to Strengthen Mathematics Learning. ProcediaSocial and Behavioral Sciences, 33, 538-542.

Zalenskiy, A. Z. 2013. Multiple Solutions of A Problem: Find the Best Point of the Shot. Australian Senior Mathematics Journal, 27 (1), 47-55. 